\title{
Diversity of AM fungi in certain ornamental plants growing at different sites of Allahabad, Uttar Pradesh, India.
}

Pragya Srivastava and Harbans Kaur Kehri*

Sadasivan Mycopathology Laboratory, Department of Botany, University of Allahabad, Allahabad-211002, Uttar

Pradesh, India.

Received: 4/10/2018; Revised: 4/19/2018; Accepted: 4/27/2018

\begin{abstract}
Use of flowers in Indian cultural and religious purposes has a central place in people's daily lifestyle. In India, increasing demand and supply of various types of flowers opened a vast scope for the production of flowers. In the present study, five important ornamental plants were collected from five different sites of Allahabad, Uttar Pradesh for the survey purpose to investigate arbuscular mycorrhizal status and diversity. All the ornamental plant species were found to be mycorrhizal but the magnitude of infection varied with the sites, plants species as well as stages of plant growth. A total of 38 species belonging to four different genera of AM fungi were isolated. Glomus was recorded as the most dominant genus with 22 species, followed by Acaulospora with 14 species, sporocarp of Sclerocystis sinuosa and Scutellospora with a single unidentified species. Study of Shannon Weiner diversity index, Species richness and Species evenness also carried out in all the five sites. Diversity of all the sites showed less variation indicating a stable and a diverse fungal community.
\end{abstract}

Key words: AM fungi, Diversity, Glomus, Ornamental plants

\section{Introduction}

Ornamental plants make a harmonious relationship between people and nature by associating the beauty and utility and make the environment beautiful and refreshing. They have a very significant economic and emotional value by displaying their lovely flowers. Flowers are one of nature's most gorgeous gifts to people. In Indian civilization use of flowers have a central place in people life as they have the language of their own. Flowers provide an everlasting impression to people by conveying different feelings and thoughts and are inseparable from the social fabric of people life. So, the international trade of floriculture getting boom day by day and there is a large demand of cut-flowers in global trade. Some major cut flowers of Indian and global markets are marigold, rose, chrysanthemum, gladiolus, tulip, carnation, orchids, etc. These ornamental plants have received an impetus worldwide. So, the growth improvement and flower production are desirable. But the cultivation of cut flowers at the commercial level is very costly for the growers because it requires high doses of fertilizers and heavy irrigation. Chemical fertilizer plays an essential role however, at the same time it also causes a set of environmental pollution and degradation of the natural environment.

In view of the above facts, there is need to focus on the potential use of biological tools such as Arbuscular Mycorrhizal (AM) fungi and plant associations to improve quality and quantity of plant resources. The microbial population are the

\footnotetext{
${ }^{*}$ Corresponding Author:

Prof. Harbans Kaur Kehri,

Sadasivan Myco-Pathology Laboratory,

Department of Botany, University of Allahabad,

Allahabad-211002, Uttar Pradesh, India.

E-mail: kehrihk@gmail.com
}

key component of soil plant system as they ensure the adequate level of production and improve the plant growth by providing the enhanced P uptake and other essentials nutrients. About $80 \%$ of terrestrial plant species are known to form AM symbiosis. They pay a significant contribution to shaping the plant community structure through the enhanced supply of minerals and water.

To explore the potentiality of AM fungi in improving the production of cut flowers it is essential to know their mycorrhizal status and host plants dependency on them. In this regard, the present work has been undertaken to study the mycorrhization, diversity, species richness and evenness of AM fungi associated with some ornamental plants cultivated at different sites of Allahabad.

\section{Materials and Methods}

\section{Sample Collection}

For the isolation of AMF spores, during each sampling $100 \mathrm{~g}$ soil was collected randomly in sterile polythene bags from each plant growing site. Root samples of the plants were also collected for the estimation of mycorrhizal infection. A set of five individuals per plant species was collected and mixed. Samples were brought back to the laboratory and the roots of the plants along with the fine roots present in the rhizospheric soils were washed with tap water and processed for the determination of root colonization. Soil samples were air dried in 
shade at room temperature and sieved for the estimation of AMF spore population and diversity.

\section{Analysis of soil samples}

Collected soil samples were air dried, sieved and packed in a polybag. Estimation of physico-chemical properties like EC, $\mathrm{pH}$, phosphorus, potassium, nitrogen and organic carbon were done from Motilal Nehru Farmers Training Institute, IFFCO Phulpur, Allahabad, Uttar Pradesh. Soil characteristics of different sites are presented in Table 1.

\section{Determination of AMF Spore Population}

AMF spore population was determined in $10 \mathrm{~g}$ air dried soil in triplicates for each sample by wet sieving and decanting method (Gerdemann and Nicolson, 1963). Soil solution was passed through the sieves of $500 \mu \mathrm{m}, 210 \mu \mathrm{m}, 150 \mu \mathrm{m}, 90 \mu \mathrm{m}$ and $60 \mu \mathrm{m}$ in descending order. AMF spores were transferred on filter papers, which were counted under a stereoscopic binocular. Number of spores were expressed as the mean of three replicates.

\section{Identification of AM Fungi}

AMF spores were mounted in polyvinyl lactoglycerol (PVLG) and PVLG + Melzer's reagent (1:1 v/v) and identified up to the species level using the synoptic keys of Trappe (1982), Schenck and Perez (1987) and INVAM species guide (http;//invam.wvu.edu).

Assessment of AM fungal Colonization in the Roots

Intensity of AM colonization in the root samples was determined by the method of Phillips and Hayman (1970). For the quantification of AM colonization, 100 root bits were mounted on slides (10 per slide) and examined under a compound microscope (CH20i, Olympus). Mycorrhizal intensity in the roots was expressed in the terms of percent root bits infected and was calculated as follows:

$$
\begin{aligned}
& \text { Mycorrhizal intensity } \\
& =\frac{\text { Number of root bits infected }}{\text { Total number of root bits examined }} \times 100
\end{aligned}
$$

Frequency, Abundance, Density, Diversity, Richness and Evenness of AM Fungi species

Species frequency, abundance, density, diversity, richness and evenness of AM fungi were expressed as follows:

Frequency $=$

Number of sites/plants at which AMF sp. occurred at once X 100

Abundance $=$

$$
\text { Total number of sites/plants }
$$

Total number of AMF sp. at all sites/plants

Number of sites/plants where the AMF sp. occurred at once

Density $=\frac{\text { Total number of AMF sp. at all sites } / \text { plants }}{\text { Total number of sites/plants }}$

AMF species diversity was calculated by following formula:

Shannon-Weiner diversity index $=-\sum_{\mathrm{i}=1}^{\mathrm{s}}(\mathrm{Pi} \ln \mathrm{Pi})$

$\mathrm{Pi}=$ proportion of individual of species $\mathrm{i}$
Species richness is calculated by Margalef's indices of richness $=(\mathrm{S}-1) / \ln \mathrm{N}$

Species evenness is calculated by

$$
\text { Pielou's index }=\frac{\mathrm{H} \prime}{\mathrm{H} / \max }
$$

$\mathrm{H}^{\prime}=$ Shannon-Weiner diversity index

$\mathrm{H}^{\prime} \max =$ maximum Shannon-Weiner diversity index

\section{Results and Discussion}

The arbuscular mycorrhizal status in terms of mycorrhizal infection in roots and spore population in the rhizospheric soils were expressed. The root and soil samples of five ornamental plants viz., Tagetes erecta L., Calendula officinalis L., Aster amellus L., Dablia pinnata Cav. and Rosa indica L. belonging to two different familes i.e. Asteraceae and Rosaceae were collected at different stages of growth viz, vegetative, budding and flowering from different ornamental sites of Allahabad. These sites were Roxburgh Botanical garden, Company garden, Anand Bhawan campus, Sam Higginbottom Institute of Agriculture, Technology and Sciences (SHIATS) campus and Jhunsi nursery (Plate-1).

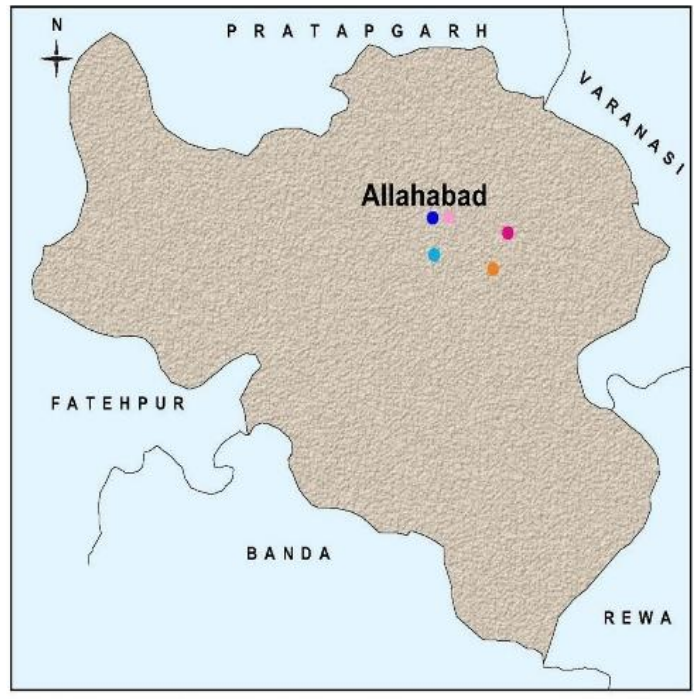

Plate 1. Map of Allahabad Showing Survey Sites

- Roxburgh Botanical Garden

- Anand Bhavan

- Company Garden

- SHIATS

- Jhunsi Nursery

All the ornamental plants showed mycorrhizal infection in their roots. However, the magnitude of infection and spore population varied with the sites plant species and stages of plant growth. Minimum root bit infection was recorded at the vegetative stage while maximum at flowering stage. The average range of infection varied from $19.3 \%$ to $55.7 \%$. Maximum infection was recorded in Marigold at SHIATS while minimum in Rose at Jhunsi nursery (Fig. 1 and Plate 2). 


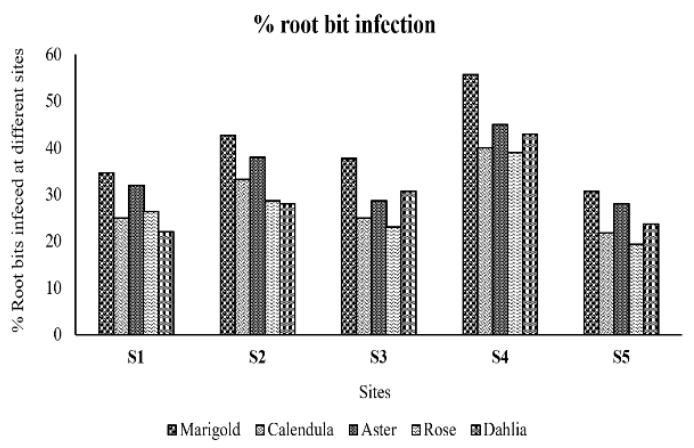

Figure 1. Showing \% root bits infected in different ornamental plants from different ornamental sites

S1- Roxburgh Botanical Garden

S2- Company Garden

S3- Anand Bhawan Campus

S4- SHIATS

S5- Jhunsi Nursery

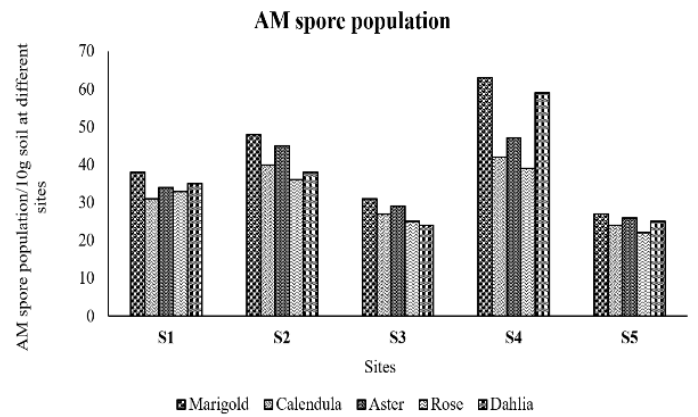

Figure 2. Showing AMF spore population in different ornamental plants from different ornamental sites

S1- Roxburgh Botanical Garden

S2- Company Garden

S3- Anand Bhawan Campus

S4- SHIATS

S5- Jhunsi Nursery
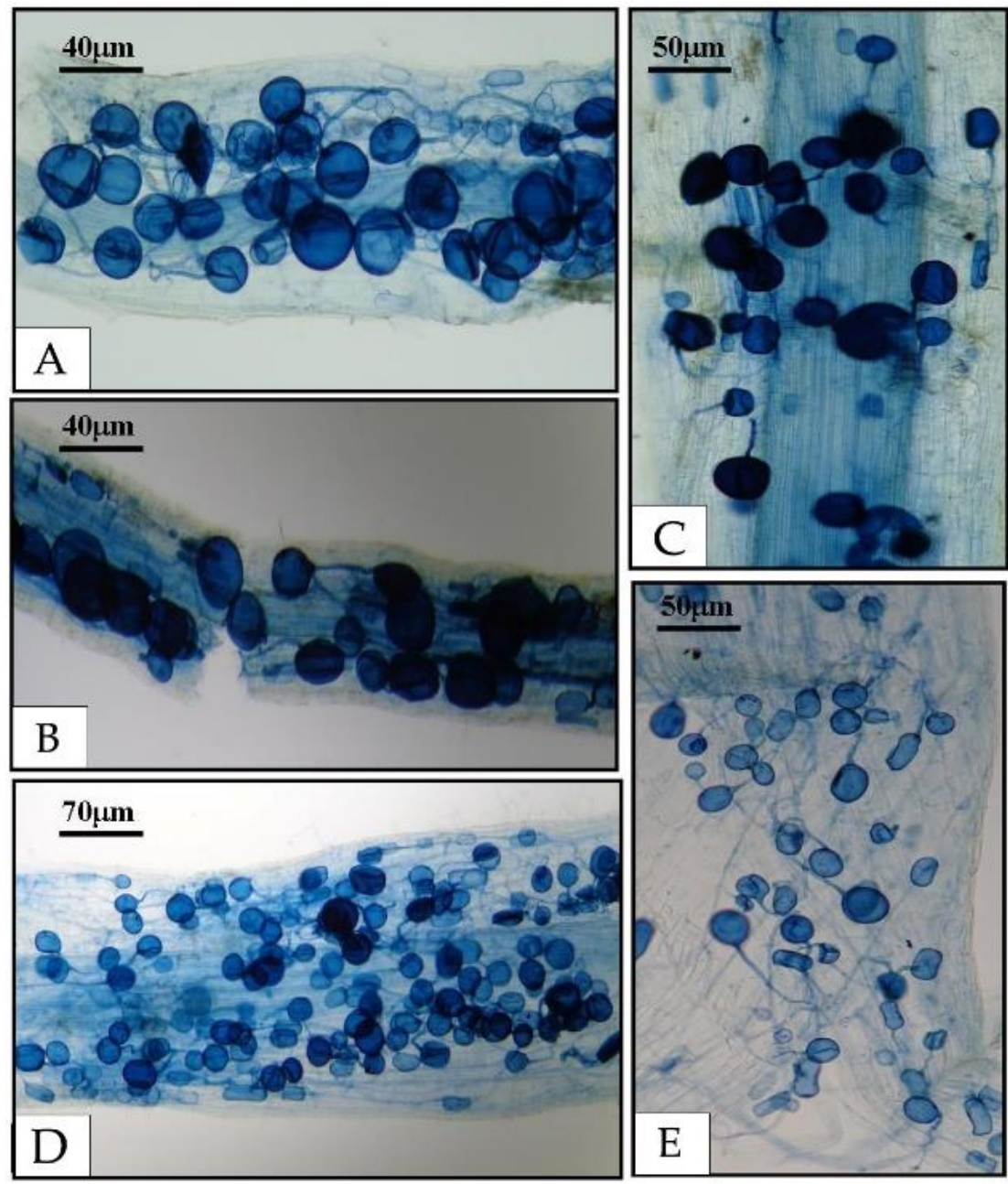

Plate 2. Root bits infection in the roots of ornamental plants collected from different sites of Allahabad, Uttar Pradesh.
A- Roxburgh Botarical Garden
D- SHIATS
B- Company Garden
E- Jhunsi Nursery
C- Anand Bhavan Campus

In the same way, the range of AMF spore population varied from 22.0 to 63.0 spores $/ 10 \mathrm{~g}$ air dried soil. Minimum spore population was recorded at vegetative stage while the maximum at flowering stage. Maximum spore population was recorded in Marigold at SHIATS while minimum in Rose at Jhunsi nursery (Fig. 2 and Plate 3) 

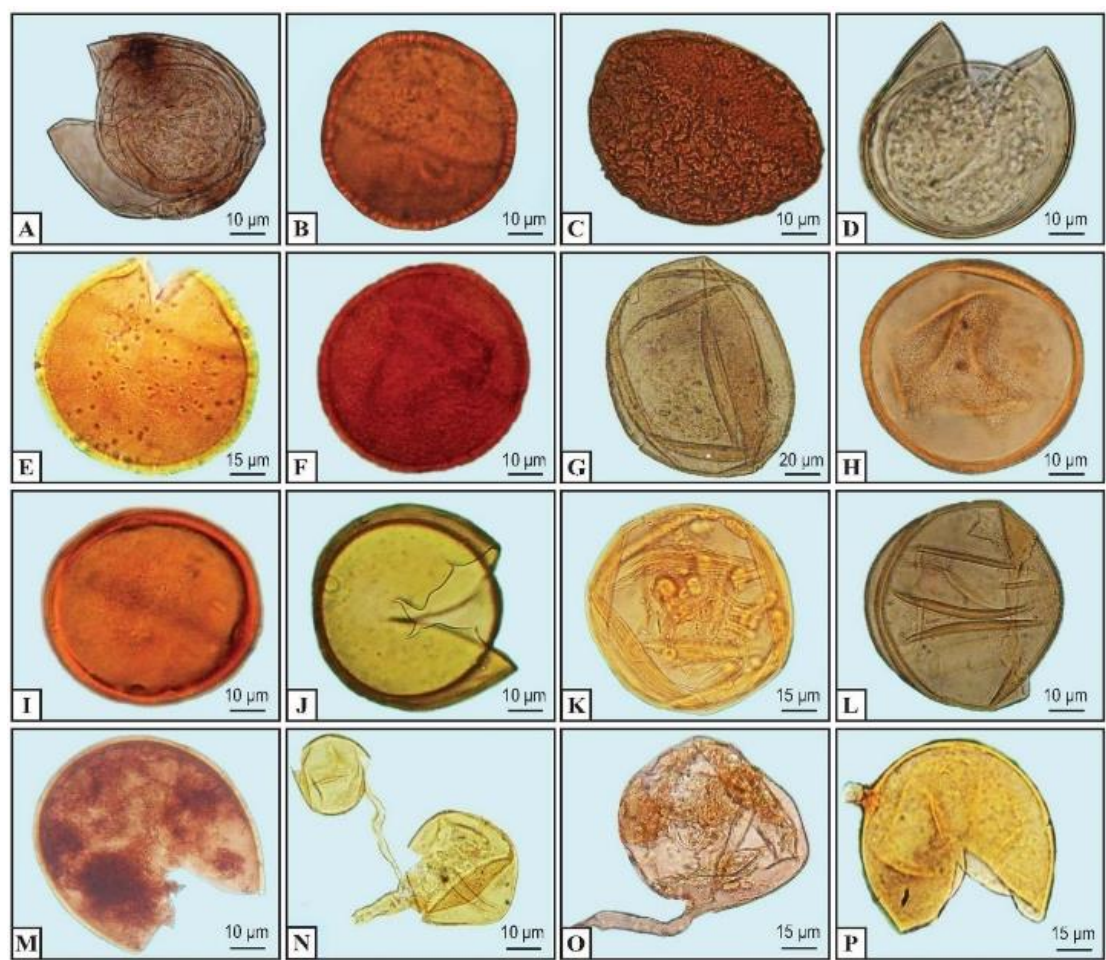

Plate 3. AM spores isolated from the rhizospheric soil of ornamental plants of different sites:
A. Acaulospora colombiana (Spain and Schenck) Kaonongbua, Morton and Bever
B. Acaulospora denticulata Sieverding and Toro C. Acaulospora foveata Trappe and Janos
D. Acaulospora delicata Walker, Pfeiffer and Bloss E. Acaulospora lacunose Morton
F. Acaulospora laevis Gerdemann and Trappe G. Acaulospora longula Spain and Schenck
H. Acaulospora scrobiculata Trappe I. Acaulospora trappei Ames and Linderman
J. Acaulospora sp. 1 K. Acaulospora sp. 2 L. Acaulospora sp. 3 M. Acaulospora sp. 4
N. Glomus aggregatum Schenck and Smith emend. Koske O. Glomus albidum Walker and
Rhodes P. Glomus ambisporum Smith and Schenck

Diversity, Density, Frequency, Abundance, Species richness and Species evenness at different survey sites of Allahabad

A variety of AMF spores were recovered from the rhizospheric soils of the plants from different survey sites and identified as mentioned above. A total of 38 species belonging to four different genera of AM fungi were isolated as the most dominant forms associated with the ornamental plants. Glomus was recorded as the most dominant genus with 22 species, vi\%. G. aggregatum Schenck and Smith emend. Koske, G. albidum Walker and Rhodes, G. ambisporum Smith and Schenck, G. caledonium (Nicolson and Gerd.) Trappe and Gerdemann, G. claroideum Schenck and Smith, G. constrictum Trappe, G. deserticola Trappe, Bloss and Menge, G. fasciculatum (Thaxt.) Gerdemann and Trappe, G. fuegianum (Speg.) Trappe and
Gerdemann, G. geosporum (Nicolson and Gerd.) Walker, G. gerdmanii Rose, Daniels and Trappe, G. intraradices Schenck and Smith, G. macrocarpum Tul. and C. Tul., G. mosseae (Nicolson and Gerd.) Gerdemann and Trappe, G. multicaule Gerdemann and Bakshi, G. occultum Walker, G. tortuosum Schenck and Smith and five unidentified named Glomus sp. 1 to 5 followed by Acaulospora with 14 species vi\%. $A$. colombiana (Spain and Schenck) Kaonongbua, Morton and Bever, $A$. delicate Walker, Pfeiffer and Bloss, $A$. denticulata Sieverding and Toro, $A$. foveata Trappe and Janos, A. lacunosa Morton, A. laevis Gerdemann and Trappe $A$. longula Spain and Schenck, $A$. scrobiculata Trappe, $A$. trappei Ames and Linderman, $A$. tuberculata Janos and Trappe and four unidentified named Acaulospora sp.1 to 4, sporocarp of Sclerocystis sinuosa Gerd. and Bakshi and Scutellospora with one unidentified species named Scutellospora sp. (Table2).

Table 1. Edaphic features of the soils of different sites of Allahabad included in the survey

\begin{tabular}{|c|c|c|c|c|c|c|c|}
\hline Sites & Soil texture & $\mathrm{pH}$ & $\begin{array}{c}\text { EC } \\
\left(\mathrm{m} \cdot \mathrm{mhos}^{\left.-\mathrm{cm}^{-1}\right)}\right.\end{array}$ & $\begin{array}{c}\text { Organic } \\
\text { Carbon } \\
(\%)\end{array}$ & $\begin{array}{c}\text { Nitrogen } \\
(\%)\end{array}$ & $\begin{array}{l}\text { Phosphorus } \\
\text { (Kg/ha) }\end{array}$ & $\begin{array}{c}\text { Potassium } \\
(\mathrm{Kg} / \mathrm{ha})\end{array}$ \\
\hline Anand Bhawan Campus & loam & 7.8 & 1.53 & 0.69 & 0.57 & 33.00 & 242.0 \\
\hline Company Garden & loam & 7.2 & 0.55 & 0.74 & 0.53 & 21.00 & 249.0 \\
\hline Jhunsi Nursery & loam & 7.6 & 0.77 & 0.43 & 0.38 & 31.00 & 253.0 \\
\hline $\begin{array}{l}\text { Roxburgh } \quad \text { Botanical } \\
\text { Garden }\end{array}$ & loam & 7.6 & 0.74 & 0.56 & 0.35 & 26.00 & 247.0 \\
\hline SHIATS Campus & loam & 7.4 & 0.42 & 0.97 & 0.41 & 25.00 & 239.0 \\
\hline
\end{tabular}


Table 2. Diversity, density, frequency, abundance, species richness and species evenness of dominant AM fungi collected from different survey sites of Allahabad

\begin{tabular}{|c|c|c|c|c|c|c|c|c|}
\hline \multirow{2}{*}{ AM Fungi/Survey Sites } & \multicolumn{8}{|c|}{ AM Fungi Diversity } \\
\hline & S1 & S2 & S3 & $\mathrm{S} 4$ & S5 & $\mathbf{D}$ & $\mathbf{F}$ & $\mathbf{A}$ \\
\hline $\begin{array}{l}\text { Acaulospora colombiana (Spain and Schenck) Kaonongbua, } \\
\text { Morton and Bever }\end{array}$ & - & - & 1 & - & - & 0.2 & 20 & 1 \\
\hline Acaulospora delicata Walker, Pfeiffer and Bloss & - & - & 1 & - & 2 & 0.6 & 40 & 1.5 \\
\hline Acaulospora denticulata Sieverding and Toro & 1 & 1 & - & - & - & 0.4 & 40 & 1 \\
\hline Acaulospora foveata Trappe and Janos & 4 & - & 1 & 3 & - & 1.6 & 60 & 2.7 \\
\hline Acaulospora lacunosa Morton & - & 1 & 2 & 1 & 1 & 1 & 80 & 1.25 \\
\hline Acaulospora laevis Gerdemann and Trappe & - & 3 & - & 6 & 2 & 2.2 & 60 & 3.6 \\
\hline Acaulospora longula Spain and Schenck & - & 3 & - & - & - & 0.2 & 20 & 3 \\
\hline Acaulospora scrobiculata Trappe & 1 & 2 & - & - & - & 0.6 & 40 & 1.5 \\
\hline Acaulospora trappei Ames and Linderman & 3 & 5 & 2 & 3 & - & 2.6 & 80 & 3.25 \\
\hline Acaulospora tuberculata Janos and Trappe & - & - & - & 5 & - & 1 & 20 & 5 \\
\hline Acaulospora sp.1 & 2 & 1 & - & - & - & 0.6 & 40 & 1.5 \\
\hline Acaulospora sp.2 & - & - & - & 3 & 1 & 0.8 & 40 & 2 \\
\hline Acaulospora sp. 3 & 1 & - & 1 & - & 1 & 0.6 & 60 & 1 \\
\hline Acaulospora sp.4 & - & 1 & - & - & - & 0.2 & 20 & 1 \\
\hline Glomus aggregatum Schenck and Smith emend. Koske & 4 & 1 & - & - & - & 1 & 40 & 2.5 \\
\hline Glomus albidum Walker and Rhodes & - & - & 2 & - & - & 0.4 & 20 & 2 \\
\hline Glomus ambisporum Smith and Schenck & - & 2 & - & - & - & 0.4 & 20 & 2 \\
\hline $\begin{array}{l}\text { Glomus caledonium (Nicolson and Gerd.) Trappe and } \\
\text { Gerdemann }\end{array}$ & - & 1 & - & 3 & - & 0.4 & 40 & 2 \\
\hline Glomus claroideum Schenck and Smith & 2 & - & - & 1 & - & 0.6 & 40 & 1.5 \\
\hline Glomus constrictum Trappe & - & 2 & - & 3 & 3 & 1.6 & 60 & 2.6 \\
\hline Glomus deserticola Trappe, Bloss and Menge & - & - & 3 & - & 1 & 0.8 & 40 & 2 \\
\hline Glomus fasciculatum (Thaxt.) Gerdemann and Trappe & 2 & 3 & - & 7 & - & 2.4 & 60 & 4 \\
\hline Glomus fuegianum (Speg.) Trappe and Gerdemann & - & - & 1 & - & - & 0.2 & 20 & 1 \\
\hline Glomus geosporum (Nicolson and Gerd.) Walker & 1 & - & - & - & 1 & 0.4 & 40 & 1 \\
\hline Glomus gerdmanii Rose, Daniels and Trappe & 1 & - & - & - & - & 0.2 & 20 & 1 \\
\hline Glomus intraradices Schenck and Smith & - & 1 & 2 & 4 & - & 1.4 & 60 & 2.3 \\
\hline Glomus macrocarpum Tul. and C. Tul. & - & 1 & - & - & - & 0.2 & 20 & 1 \\
\hline Glomus mosseae (Nicolson and Gerd.) Gerdemann and Trappe & 4 & 3 & 2 & 8 & - & 3.4 & 80 & 4.25 \\
\hline Glomus multicaule Gerdemann and Bakshi & - & - & - & 1 & 1 & 0.4 & 40 & 1 \\
\hline Glomus occultum Walker & 1 & - & - & 1 & 2 & 0.8 & 60 & 1.3 \\
\hline Glomus tortuosum Schenck and Smith & 2 & 3 & - & 4 & - & 1.8 & 60 & 3 \\
\hline Glomus sp.1 & - & 1 & - & 3 & - & 0.8 & 40 & 2 \\
\hline Glomus sp.2 & - & - & 2 & - & 1 & 0.6 & 40 & 1.5 \\
\hline Glomus sp.3 & 2 & - & - & - & - & 0.4 & 20 & 2 \\
\hline Glomus sp.4 & - & - & - & 1 & 2 & 0.6 & 40 & 1.5 \\
\hline Glomus sp. 5 & 1 & - & - & - & - & 0.2 & 20 & 1 \\
\hline Sclerocystis sinuosa Gerd. and Bakshi & - & - & - & 2 & - & 0.4 & 20 & 2 \\
\hline Scutellospora sp. & - & - & 1 & 2 & - & 0.6 & 40 & 1.5 \\
\hline Total no. of AMF spores & 32 & 35 & 21 & 61 & 18 & & & \\
\hline Shanon diversity index & 2.63 & 2.74 & 2.49 & 2.76 & 2.40 & & & \\
\hline Species richness & 4.33 & 4.78 & 3.94 & 4.38 & 3.81 & & & \\
\hline Species evenness & 0.86 & 0.86 & 0.93 & 0.83 & 0.92 & & & \\
\hline
\end{tabular}

D- Density F- Frequency A- Abundance

S1- Roxburgh Botanical Garden; S2- Company Garden; S3- Anand Bhawan Campus; S4- SHIATS; S5- Jhunsi Nursery

Density of $G$. mosseae was recorded to be maximum (3.4) while minimum of $A$. colombiana, A. longula, Acaulospora sp.4, G. fuegianum, G. gerdmanii, G. macrocarpum and Glomus sp. 5 (0.2). The frequency of AMF spores was found to be ranged from 20 to 80 . The abundance of AMF spores was also recorded and found to be ranged from 1.0 to 4.25. ShannonWeiner diversity index of AMF spores at different sites was analyzed and found to be maximum at SHIATS (2.76) and minimum at Jhunsi nursery (2.40) (Fig. 3). AMF species richness at different sites was found to be ranged from 3.81 to 4.78 (Fig. 4) while the Pielou's index of AMF species evenness was found to be ranged from 0.83 to 0.93 (Fig. 5) (Table-2).

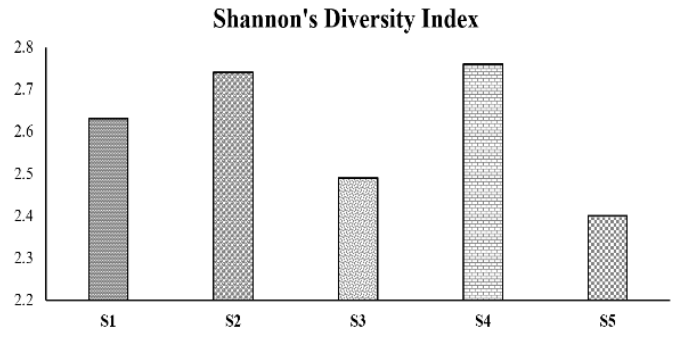

Figure 3. Showing Shannon's Diversity Index of AM fungi at different sites

S1- Roxburgh Botanical Garden

S2- Company Garden

S3- Anand Bhawan Campus

S4- SHIATS

S5- Jhunsi Nursery

AM fungi can be recognized as 'keystone mutualists' (Kumar et al., 2010). In all terrestrial ecosystem, about $80 \%$ of plant taxa develop AM symbiosis 
between plant roots and soil fungi (Smith and Read, 2008). Almost all the families of Angiosperms are reported to be colonized by AM fungi (Malloch et al., 1980). Though they show little or no host specificity to the plant species (Ahulu et al., 2007; Opik et al., 2009; Santos-Gonzalez et al., 2007) but from place to place their occurrence and distribution is diverse and varies.

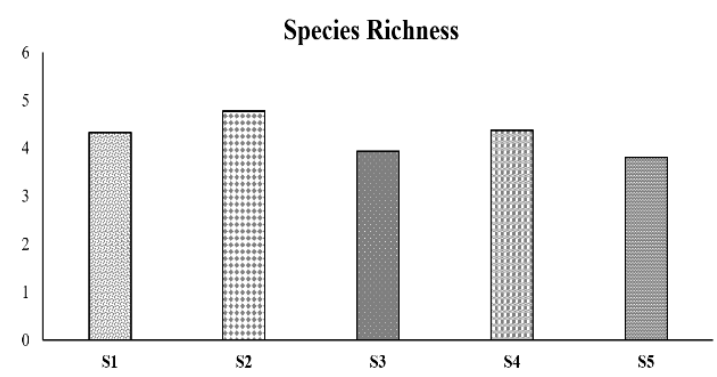

Figure 4. Showing Species Richness of AM fungi at different sites

S1- Roxburgh Botanical Garden

S2- Company Garden

S3- Anand Bhawan Campus

S4- SHIATS

S5- Jhunsi Nursery

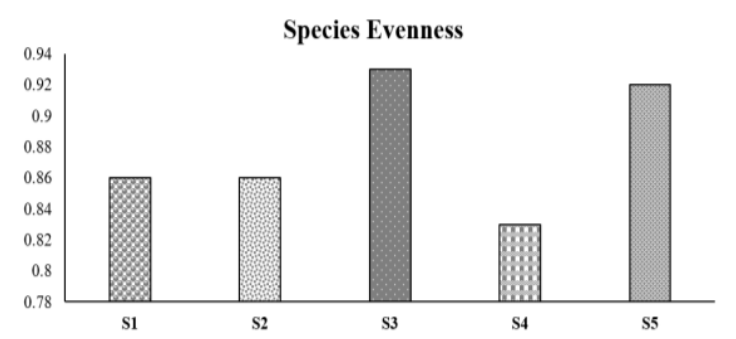

Figure 5. Showing Species Evenness of AM fungi at different sites

S1- Roxburgh Botanical Garden

S2- Company Garden

S3- Anand Bhawan Campus

S4- SHIATS

S5- Jhunsi Nursery

\section{Mycorrhizal Status and Sites}

At various surveyed sites, there were significant differences in spore population and mycorrhizal intensity in the roots. All the surveyed plants were colonized by AM fungi but the magnitude of colonization varied with the taxa as well as site. Maximum mycorrhization was recorded at SHIATS campus and minimum in Jhunsi nursery site.

Soil status of all the survey sites under study showed substantial variations in their $\mathrm{pH}$, electrical conductivity as well as nitrogen, phosphorus, potassium and organic carbon contents. These fluctuations in soils might have been responsible for the variations in the mycorrhizal status of the ornamental plants at different sites.

Several workers reported the AM dependency on physico-chemical properties of soils such as $\mathrm{pH}$ (Read et al., 1976; Raman and Sambandan, 1998), EC, organic carbon (Raman and Sambandan, 1998), total nitrogen (Beena et al., 2000), phosphorus (Selvaraj et al., 2001) and potassium levels (Schalamuk et al., 2006). A negative relation was observed between soil phosphorus and AMF spores Janaki and Manoharachary, 1994). High P in soil reduced the root colonization, spore production and hyphal growth (Abbot and Robson, 1991; Covacevich et al., 2007). These reports are in conformity with the present findings.

\section{Mycorrhizal status with different Ornamental Plants}

The ornamental plants which are included in the survey were found to be colonized by AM fungi but the status of mycorrhization varied with the different ornamental plant species. Maximum AMF spore population and mycorrhizal association were recorded in marigold and minimum in rose. Many other workers also reported the AM fungal colonization in ornamental plants (Rekha et al., 1987; Kumar et al., 2012). Although AM fungi show little or no host specificity. It was found that some plant species have higher response to AM fungi while others are less responsive (Bagyaraj, 2011; Bagyaraj et al., 2015). Various factors are responsible for AM fungi community composition that alter the soil and rhizospheric atmosphere including root exudates pattern, plant host morphology and supply of $\mathrm{C}$ to fungus in roots. Root exudates quality and quantity and the surface of root affect the number of infection sites and susceptibility of the roots to endophyte penetration. For AM symbiosis these factors might be stimulatory or inhibitory in nature and might be the cause of differential mycorrhizal status of diverse ornamental plants.

\section{Mycorrhizal Status and Stages of Plant Growth}

Colonization in the roots of the different plant species varied with the type of AMF propagules as well as the stages of plant growth vir., vegetative, budding and flowering. Maximum AMF spore population and $\%$ root bit infection were recorded at flowering stage while minimum at vegetative stage in ornamental plants. Javaid et al. (2007) and Kumar et al. (2012) also reported maximum mycorrhization at flowering stage and minimum at seedling stage in the ornamental plants. Our findings also showed the similar trends.

Various factors are responsible for the development of infection and spore production. Besides these, the physiology and nutrient status of the host, root susceptibility to the penetration by the symbiont and root exudation pattern are the prominent ones (Jungk, 1994). Jakobsen and Nielson (1983) reported that because of the variation in these factors the mycorrhizal status of the plants also show variation with growth stages.

\section{Mycorrhizal association and Diversity}

Less variation in Shannon Wiener Diversity index study representing a stable and diverse AM fungal community (Fowler and Antonovics, 1981). 
Brundrett and Kendrick (1990) and Radhika and Rodrigues (2010) reported that due to interspecific competition, variation in spore number and species in the rhizospheric soil and roots may possible or it may due to environmental factors which affect the spore production in natural communities (Gemma and Koske, 1988; Radhika and Rodrigues, 2010).

Glomus mosseae has been found abundantly in all the sites and frequency and density is also high. The possible cause might be because of its wider niche, strongest competitor among all and no host preference. Among all the sites no significant difference was found in species evenness. High diversity and ecosystem productivity are recognized from the high value of species richness and species evenness.

\section{Conclusion}

The present study concluded that all the ornamental plants showed mycorrhizal colonization but their dependency on AM fungi varied with the sites, plant species and stages of plant growth. Due to the wide occurrence of Acaulospora and Glomus species in the soil, it can be used for the mass multiplication and use as a microbial inoculant for the better growth of ornamental plants with the reduced cost of chemical fertilizer.

\section{Acknowledgements}

The authors are thankful to University Grant Commission (UGC), New Delhi for providing financial assistance. Authors are also thankful to Motilal Nehru Farmer's Training Institute IFFCO, Phulpur, Allahabad for conducting soil analysis.

\section{References}

1. Abbot, LK and AD Robson. "Factors influencing the occurrence of vesicular-arbuscular mycorrhizas." Agriculture, Ecosystems and Environment 35 (1991): 121150.

2. Ahulu, EM, H Andoh and M Nonaka. "Host-related variability in arbuscular mycorrhizal fungal structures in roots of Hedera rbombea, Rubus parvifolius and Rosea multiflora under control conditions." Mycorrbiza 17 (2007): 93-111.

3. Bagyaraj, DJ. "Microbial Biotechnology for Sustainable Agriculture, Horticulture and Forestry." NIPA Publishers, New Delhi. (2011). Pp: 308.

4. Bagyaraj, DJ, MP Sharma and D Maiti. "Phosphorus nutrition of crops through arbuscular mycorrhizal fungi." Current Science 108 (2015): 1288-1293.

5. Beena, KR, NS Raviraja, AB Arun and KR Sridhar. "Diversity of arbuscular mycorrhizal fungi on the coastal sand dunes of the west coast of India." Current Science 79.10 (2000): 1459-1466.

6. Brundrett, MC and B Kendrick. "The roots and mycorrhizas of herbaceous woodland II. Structural aspects of morphology." New Phytologist 114 (1990): 469-479.

7. Covacevich, F, HEA Echeverria and LAN Aguirrezabal. "Soil available phosphorus status determines indigeneous mycorrhizal colonization of field and glasshouse-grown spring wheat from Argentina." Applied Soil Ecology 35 (2007): 1-9.

8. Fowler, $\mathrm{N}$ and $\mathrm{J}$ Antonovics. "Competition and coexistence in North Carolina grassland I. Patterns in undisturbed vegetation.” Journal of Ecology 69 (1981): 825-841.

9. Gemma, JN and RE Koske. "Seasonal variation in spore abundance and dormancy of Gigaspora gigantia and in mycorrhizal inoculum potential of a dune soil." Mycologia 80 (1988): 211-216.

10. Gerdemann, JW and TH Nicolson. "Spores of mycorrhizal Endogone species extracted from soil by wet sieving and decanting." Transactions of the British Mycological Society 46 (1963): 235-244.

11. Jakobsen, I and Neilsen NE. "Vesicular-arbuscular mycorrhiza in field grown crops. I. Mycorrhizal infection in cereals and peas at various times and soil depths." New phytologist 93 (1983): 401-413.

12. Janaki, R and C Manoharachary. "VA mycorrhizal association of safflower in relation to physicochemical characters." Journal of Soil Biology and Ecology 14 (1994): 41-50.

13. Javaid, A, T Riaz and Khan SN. "Mycorrhizal status of Narcissus papyraceus Ker-Gawl. Co-cultivated with Cynodon dactylon Pers." International Journal of Agriculture and Biology 9.6 (2007): 901-904.

14. Jungk, A. "Phosphorous supply of plants-how it is accomplished?" Proceeding of the National Science Council, Republic of China 18 (1994): 187-197.

15. Kumar, A, SK Bhatti and A Aggarwal. "Biodiversity of endophytic mycorrhiza in some ornamental flowering Plants of Solan, Himachal Pradesh." Biological Forum 4.2 (2012): 45-51.

16. Kumar, A, C Mangla, A Aggarwal and V Parkash. "Arbuscular Mycorrhizal fungal dynamics in the Rhizospheric soil of Five Medicinal plant species." Middle- East Journal of Scientific Research 6.3 (2010): 281288.

17. Malloch, DW, KA Pirozynsky and PH Raven. "Ecological and evolutionary significance of mycorrhizal symbiosis in vascular plants." Proceedings of the National Academy of Sciences USA 77 (1980): 21132118.

18. Opik, M, M Metsis, TJ Daniell, $M$ Zobel and $M$ Moora. "Large-scale parallel 454 sequencing reveals host ecological group specificity of arbuscular mycorrhizal fungi in a boreonemoral fores." New Phytologist 184 (2009): 424-437.

19. Phillips, JM, DS Hayman. "Improved procedure for clearing roots and staining parasitic and vesicular- 
arbuscular mycorrhizal fungi for rapid assessment of infection." Transactions of the British Mycological Society 55 (1970) 158.

20. Radhika, KP and BF Rodrigues. "Arbuscular mycorrhizal fungal diversity in some commonly occurring medicinal plants of Western Ghats, Goa region.” Journal of Forestry Research 21.1 (2010): 45-52.

21. Raman, N and K Sambandan. "Distribution of VAM fungi in tannery effluent polluted soils of Tamil Nadu, India." Bulletion of Environmental Contamination and Toxicology 60 (1998): 142-150.

22. Read, DJ, HK Koucheki and J Hodgson. "Vesicular arbuscular mycorrhiza in natural vegetation systems. I. The occurrence of infection." New Phytologist 77 (1976): 641-653.

23. Rekha, R, J Rano and KG Mukerji. "Mycorrhizal status of some ornamental plants at their reproductive and vegetative stage." Acta Botanika 15 (1987): 311-313.

24. Santos-Gonzalez, JC, S Nallanchakravarthula, S Alstrom and RD Finlay. "Soil, but not cultivar, shapes the structure of arbuscular of arbuscular mycorrhizal fungal assemblages associated with strawberry." Microbial Ecology 62 (2011): 25-35.
25. Schalamuk, S, S Velazquez, H Chidichimo and M Cabello. "Fungal spores diversity of arbuscular mycorrhizal fungi associated with spring wheat: effects of tillage." Mycologia 98.1 (2006): 16-22.

26. Schenck, NC and Y Perez. "Manual for the identification of VA mycorrhizal fungi." INVAM, University of Florida, Gainesville, USA. (1987).

27. Selvaraj, T, R Murugan and C Bhaskaran. "Arbuscular mycorrhizal association of Kashini (Cichorium intybus L.) in relation to physico-chemical characters." Mycorrbiza News 13.2 (2001): 14-16.

28. Smith, SE and DJ Read. Mycorrhizal symbiosis $3^{\text {rd }}$ Edn. Academic Press, London. (2008).

29. Trappe, JM. "Synoptic keys to the genera and species of zygomycetous mycorrhizal fungi." New Phytologist 72 (1982): 1102-1108.

\section{Cite this article as:}

Pragya Srivastava and Harbans Kaur Kehri. Diversity of AM Fungi in Certain Ornamental Plants Growing at Different Sites of Allahabad, Uttar Pradesh, India. Annals of Plant Sciences 7.5 (2018) pp. 2231-2238.

do $\mathrm{http://dx.doi.org/10.21746/aps.2018.7.5.5}$

Source of support: U.G.C., New Delhi, India.

Conflict of interest: Nil 